\title{
Increased line efficiency by improved work methods with the ECRS concept in a washing machine production: a case study
}

\author{
Asariella Findya Octa Pertiwi*, Rahmaniyah Dwi Astuti
}

Department of Industrial Engineering, Universitas Sebelas Maret, Jalan Ir.Sutami No. 36A, Surakarta, Jawa Tengah 57126, Indonesia

\begin{tabular}{l} 
ARTICLE INFORMATION \\
\hline Article history: \\
Received: April 25, 2020 \\
Revised: June 18, 2020 \\
Accepted: June 28, 2020 \\
\hline Keywords: \\
Work method \\
ECRS \\
Manufacturing \\
Productivity \\
Line efficiency
\end{tabular}

*Corresponding Author

Asariella Findya Octa Pertiwi

E-mail: findya.octa26@gmail.com

\section{A B S T R A C T}

The Assembly line is the assembly process that is carried out based on the order of the production process in the production line. The problem that is often found in assembly lines is bottleneck conditions where some material piled up at the station. This situation indicates an imbalance in the production line. The improvement of the work method is one of the effective ways that can increase line efficiency. This study presents an increase in line efficiency by improving working methods in a washing machine assembly line of PT.X. The study aimed to increase the value of line efficiency by improving work methods. In this study, improvements were made using the line balancing method and Eliminate, Combine, Rearrange, Simplify (ECRS) concept. The results that have been done, the obtained value of line efficiency for washing machine products is $76.76 \%$. This value has not reached the company's productivity target of $99.50 \%$. Therefore it is necessary to improve the assembling line to increase the value of product production. The proposed improvements made with improvements to the work methods on the assembling line obtained $89.38 \%$ results is to increase the amount of line efficiency by improving work methods.

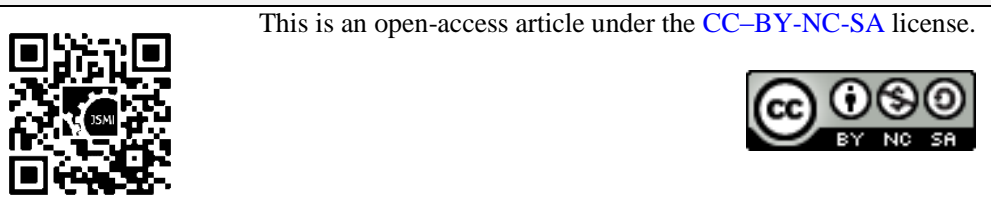

\section{INTRODUCTION}

Manufacturing Industry is one of the drivers for national economic growth that can spur the competitiveness of the domestic manufacturing sector. Innovation is used as a basis for industrialstrength to compete in an era of increasingly fierce competition. Every company is trying to compete and trying to create more profit by increasing productivity and delighting customers by meeting the expectation in terms of quality and price [1].
A challenge that is not possible to overcome industrial competition, we need a way to look for efficiency measures and optimization of the production process to obtain maximum output. In this competitive environment, companies must increase their productivity by using optimal resources to survive and continue to profit [2]. The fierce global competition, poor responsiveness, low flexibility to meet uncertain demand, and low efficiency of traditional assembly lines are 
sufficient motives to persuade producers to adopt highly flexible production equipment [3]. The manual assembly lines and assembly line balancing problems are very relevant not only for emerging economies but also for developing countries [4]. The complexity of production activities to meet the needs of market demands requires the implementation of a new program that is appropriate and per the problems that occur [5].

Lean manufacturing can be proven effective in reducing waste from the manufacturing process, and continuous improvement is needed to create added value for customers with fewer resources [6]. Lean characteristics combine just-in-time practices, work-in-progress and waste reduction, improvement strategies, defect-free production, and standardization [7]. Application of the Toyota Production System Principle to expedite the entire production area in a variety of processes, reduce waste, obtain high-quality output, improve operating procedures and produce finished goods at low production costs [8]. Lean practices in manufacturing involve the elimination of wastes, one of which is motion waste [9].

Lean manufacturing techniques are a set of tools and methods for eliminating wastes in manufacturing operations, assist in making corrective action plans, and also in improving working conditions [10]-[13]. The advantages of implementing and strengthening lean manufacturing through consistent efforts can help companies to stimulate the best strategies for dealing with the effects of the current economic crisis [14]. The goals of ergonomics and lean manufacturing are similar; improve productivity [15]. Productivity is one crucial factor to support the production process of a company by analyzing and evaluating the outputs obtained based on the level of performance during a specific period [16]. Line balancing is a useful tool to increase the production of the assembly line while reducing cycle time from non-value added activities [3].

Some researchers are trying to reduce waste by using the ECRS concept. This research is a development from previous research. Fajrianto, et. al [17] conducted a study in a manufacturing company, where the idea of the ECRS was able to eliminate unnecessary movement, thereby reducing standard time. Besides, research on ECRS was also conducted by Suhardi, et al. [18], where the ECRS concept is able to prevent bottlenecks and decrease the lead time so that balance the workload of the operator. Kasemset et al. [19] conducted a study in one electronic parts factory as a case study, where the ECRS principle was used to propose the solution to reduce material waste. In addition, research conducted by Fadlil, et al. [20], ECRS improvement can reduce the work elements in several stations, decrease total work content time, increase workstation utility and balance efficiency, decrease balance delay and smoothness index, possibly decrease the number of work stations or the number of operators so that the company can reduce direct labor costs and most importantly, achieve production targets due to decrease in overall cycle time or maximum station time and increase in production output. The implementation of the ECRS on the setup of an inline machine layout in the bearing manufacturing plant was able to reduce the total setup time. Reducing the total setup time is done by minimizing production losses in a similar batch manufacturing plant having a line layout [21]. Besides ECRS based line balancing is also used by Amran, et al.[22] concerning the improvement of the braking system production process with ECRS based line balancing. The research was able to increase line efficiency to reduce production costs.

The purpose of this study is to increase the value of line efficiency by improving work methods at the washing machine shop floor of PT.X. This research was conducted at PT. X, which is a manufacturing industry that produces electronic goods. Electronic products produced in P.T. X include radios, refrigerators, water pumps, air conditioners, fans, and washing machines. The study was conducted at the washing machine business unit in January-February 2019. The production process carried out at the washing machine business unit is an assembly process, where the assembly process of all washing machine components is made, which then checks the condition of the washing machine until the packing process.

Based on research, were found conditions that are not ideal, i.e., of the bottleneck and idle caused by the ineffectiveness of work. In the assembly process at work stations, 9 and 11 found bottleneck conditions where some material piled up at the station. While in the assembly process at work station 12 and work station 10 found dusty conditions where the operator is unemployed because of waiting for material from the previous work station. This situation reflected an imbalance in the production line. 
Imbalance of this production line can be seen from the symptoms of unemployment in some workers/machines, also the accumulation of semifinished goods on the production floor between one machine and another machine, this is caused by differences in production capacity and imbalance of operating time from the trajectory. In manufacturing/assembly companies, this balance trajectory problem will significantly affect the achievement of production output. Line balance method is needed to plan and control a production process flow because by using this method, the company can evaluate and improve its production line to maximize work efficiency to increase production output and also to minimize the imbalance of the production line [23].

Bottleneck work stations cause delays if there is an increase in demand that exceeds the capacity of the station [24]. Waste that occurs can reduce production efficiency, reduce the quality of work, and can increase processing time [8]. Therefore it is necessary to identify the bottlenecks and attempt to decrease the cycle time at the bottleneck station to increase production capacity so that the target of demand and production targets can be achieved [24]. Efforts to reduce waste can increase efficiency so that it can increase production output [25].

Based on these problems, it is necessary to make improvements as soon as possible so that the line efficiency of these lines can increase. One way to improve the working method is the ECRS concept. The ECRS concept is an easy way to reduce waste/loss [17]. The idea of ECRS can be applied to work stations to reduce waiting times for other stations, which are commonly called bottlenecks. Increased productivity will be directly proportional to the increase in company profits without the need to increase the selling price of its products [26]. The ECRS concept is straightforward to apply, where, with its simplicity, it can lead to new ideas for improvement by understanding the elements that makeup work so that we can identify waste and form an optimal workflow [18].

Efforts to minimize waste to increase line efficiency is an interesting topic to be studied. The improvement phase is to eliminate waste in each process to increase the efficiency and effectiveness of the production process [18]. The difference in research conducted by previous researchers lies in the adjustment of time. In the electronic industry is calculated based on work performance ratings to obtain a strict standard time at each work station. Some researchers also highlight the problem of increasing productivity by reducing waste.

Therefore this research discusses some improvements that are expected to be able to increase the level of production capacity. The method used in the preparation of developments is ECRS (Eliminate, Combine, Re-Arrange, Simplify), which focuses on the equal distribution of each work element performed by the operator so that it is expected to increase the value of line efficiency and increase washing machine production capacity.

\section{RESEARCH METHODS}

The research framework for increasing line efficiency by improving work methods can be explained in the several stages follows 1) Data Collection; 2) Doing the calculations for performance rating and line balancing; 4) Recapitulation of calculation results before improvement; 5) Proposed improvement using Eliminate, Combine, Rearrange, Simplify (ECRS) concept; 6) Comparison of calculation results before and after improvements.

The first stage of this research is data collection. Data collected from direct observations and results of focus group discussions with the group chief include work process flow, cycle time data, an operator working hour data, number of operators, and company targets. After that, the data is processed; the data processed in this study include the performance rating calculation, standard time calculation, and line efficiency calculation.

Performance rating calculations are performed using the Westinghouse rating. Westinghouse Electric Corporation developed this system. The Westinghouse rating consists of four factors that can determine regularity and irregularities in work, namely, skills, effort, condition, and consistency [27].

After calculating the performance rating, the performance rating value will be used to calculate cycle time, normal time, and standard time. Furthermore, the results of the time calculation will be calculated takt time, production capacity, production/head/hour, process time, and line efficiency.

The next step is to make improvements to the work method using the ECRS concept, which 
consists of eliminating, combine, re-arrange, and simplify the work elements in the assembling line in P.T. X. The translation of the ECRS concept is eliminated (eliminated unnecessary movements), combine (combined movements that can be done simultaneously, so that is more efficient), rearrange (exchanging work elements at other work stations to be more efficient), and simplify (simplifying repetitive movements). In this study, the improvement of work methods with the ECRS concept can help to reduce inefficiencies or waste of movement that occurs when carrying out an assembly at each station. Furthermore, the standard time of work elements that have been improved using the ECRS concept is calculated based on the improvements made. After obtaining the results of developments with the ECRS concept, the next step is to compare the effects of line efficiency calculations before increase with the results of predictions after the rise to find out how significant the results obtained.

Measurement of processing time is done using a stopwatch. The processing time of each work element is measured five times taken randomly. After the processing time is obtained, a uniformity and adequacy test is performed. Equations (1) to (5) are used in conducting data uniformity tests [28].

$\bar{x}=\frac{\sum x_{i}}{N}$

$\sigma=\sqrt{\frac{\sum\left(x_{i}-\bar{x}\right)^{2}}{N-1}}$

$\sigma_{\bar{x}}=\frac{\sigma}{\sqrt{N}}$

$U C L=\bar{x}+k \sigma_{x}$

$L C L=\bar{x}-k \sigma_{x}$

Where,

$\begin{array}{lll}\bar{x} & : & \text { average value of } x \\ N & : & \text { the amount of data observed } \\ x_{i} & : & \text { i-th data value } \\ \sigma & : & \text { standard deviation } \\ k & : & \text { the level of confidence } \\ U C L & : & \text { upper control limit } \\ \text { LCL } & : & \text { lower control limit. }\end{array}$

Data is said to be uniform if all $x_{i}$ are within the control limit or can be written as $L C L \leq x_{i} \leq$ $U C L$. If the data is outside of the control limit, it is omitted, and a uniformity test is carried out. According to Purnomo [28], the adequacy of data can be calculated using equation (6).
$N^{\prime}=\left[\frac{\frac{k}{s} \sqrt{N \sum x_{i}^{2}-\left(\sum x_{i}\right)^{2}}}{\sum x_{i}}\right]^{2}$

Where,

$N^{\prime}$ : the amount of data needed in theory

$s \quad: \quad$ the degree of accuracy

$k \quad: \quad$ the level of confidence

If the confidence level is $99 \%$, then $\mathrm{k}$ is 2.58 or close to 3 . If the confidence level is $95 \%$, then $\mathrm{k}$ is 1.96 or close to 2 , and if the confidence level is $68 \%$, then $\mathrm{k}$ is close to 1 . If $N^{\prime} \leq N$, then the data is stated to be sufficient for the desired level of confidence and degree of accuracy, thus the data can be processed to find the standard time. But if $N^{\prime}>N$, then the data is declared insufficient. Therefore, the observed data must be added so that it is higher than the amount of theoretically needed information [29].

After testing, the uniformity and adequacy of the data are performed normal time calculations using equation (7) and standard time calculations using equation (8).

$W_{N}=W_{C} p$

$W_{S}=W_{N}\left(\frac{100 \%}{100 \%-a l l}\right)$

Where,

$W_{N}:$ normal time in minutes

$W_{C}:$ cycle time in minutes

$p$ : performance rating

$W_{S}:$ standard time in minutes/unit

all : the percentage of allowance

Takt time is the expected time to make one unit product. In this case, targeted takt time $\left(T_{T t}\right)$ can be used as $T_{c}$ so that the minimum worker available can achieve a desired production target, takt time can be calculated using equation (9).

$T_{T t}=\frac{E O T}{Q_{d d}}$

Where,

$T_{T t} \quad:$ takt time in minute/unit

EOT : networking time in minute/day

$Q_{d d}:$ daily demand of unit products in unit/day

Production Capacity is a production capacity that can be carried out within a specified period, and calculations can be made using equation (10). 
$C p=\frac{\text { EOT } \times \text { Balance Efficiency } \times 60 \mathrm{sec}}{\text { Actual Takt Time }}$

Production/head/hour $(\mathrm{PHH})$ is the number of products that can be produced by an operator within one hour, and calculations can be made using equation (11).

PHH $=\frac{\text { Production Capacity } \times 60 \mathrm{sec}}{\text { Total Work Stations } \times \text { EOT }}$

The processing time is the length of time required to complete a production process on a production line, and calculations can be made using equation (12).

Process Time $=\frac{\text { EOT } x \text { Total Work Station }}{\text { Production Capacity }}$

According to Groover [30], balance efficiency $\left(E_{b}\right)$ can be calculated using equations (13) to (16).

$$
\begin{aligned}
& E_{b}=\frac{T_{w c}}{w T_{s}} \\
& T_{w c}=\sum_{i=1}^{n} T_{s i} \\
& T_{s}=\max \left[T_{s i}\right] \\
& T_{s i}=\sum_{k \in i} T_{e k} \\
& \text { Where, } \\
& E_{b} \quad \text { : balance efficiency } \\
& T_{w c}: \text { the time needed to do all assembly } \\
& \text { activities (work content time) in } \\
& \text { minute/unit } \\
& w \quad: \quad \text { the number of workers available } \\
& T_{s} \quad \text { : maximum available service time on } \\
& \text { the line in minute/cycle } \\
& T_{s i} \quad: \text { the time needed to complete the task } \\
& \text { at the } i \text {-th station (station time) in } \\
& \text { minute } \\
& T_{e k}: \text { the time needed to complete the task } \\
& \text { or work element } k \text { in a minute. }
\end{aligned}
$$

\section{RESULTS AND DISCUSSION}

Based on the results of data collection, it is known that the production output target $\left(Q_{d d}\right)$ on the assembly line is 800 units per day. Washing machine production has one work shift and three assembly lines where each assembly line has 12 operators with adequate network time or daily operating time (EOT) 470 minutes per shift. Thus, the targeted takt time $\left(T_{T t}\right)$ for the assembly line is 35.25 seconds/unit or 0.5875 minutes/unit. The following are the calculation results obtained from data collection and processing.

Based on the results of calculations that have been carried out, obtained a line efficiency value of $76.76 \%$. This value has not reached the company's productivity target of $99.50 \%$. Therefore it is necessary to improve the assembly line to increase the value of productivity products. The proposed improvements made with improvements to work methods in the assembly line.

Based on direct observations and brainstorming with a section head on the assembling line, cause-effect diagrams can be generated, as shown in Fig. 1. The factors that affect the target line efficiency have not been met, including human, machine, environmental, material, and method factors. In the man factor, there are two factors. Namely, the operator handles defect products because the operator is less thorough, and the operator talks while working. On the machine factor, there is one contributing factor, which is the reliability of the engine, which is starting to decrease due to less regular engine maintenance. The security of the engine began to fall, marked by screws that are not installed on the electric screwdriver. The method factor is that there is one contributing factor: the work consumes a lot of time caused by unnecessary motion elements. In the material factor, there are two factors, namely material shortage caused by late material supply and the material defect caused by the quality of the material being input in the process is not good. After that, here are two factors causing the environment, namely noisy work areas and narrow work areas. The causes of not achieving the company's target line efficiency will be presented in Fig. 1.

The ECRS (Eliminate, Combine, Rearrange, Simplify) concept is one of the methods used to improve work methods and balance the production line. The proposed improvement is carried out to increase line efficiency and productivity of assembling lines. The time used in the ECRS concept is the standard time with the Westinghouse rating is 1.16 .

Improvements to the work method with the ECRS concept can be seen in Fig. 2. The following are details of the improvements made, namely:

\section{a. Eliminate}

Eliminate method is a method that removes a 
work element that is deemed inefficient so that it can reduce processing time. Repair work elements by eliminating ECRS 1, 2, 3, 4, 9, 11, 12, 13, and 15. Elimination of unnecessary work elements occurs at work stations 1,2,8, 9, and 11. At work station 1, work elements 6 and 14, namely taking the nut and attaching it to the bolt. The work can be done by the supplier so that the operator of the motor assembly work station can install and tighten the bolt and nut on the brake wheel without the bolt and nut installation process so that the process is able to save the time of 3.14 seconds and 3.01 seconds. At work station one on working element 12 , which is to take the vinyl tie and tie the wire to the bracket. The work can be done at an offline station, where during the wash and spin motor preparation process when it is placed on the pallet so that the operator can do the next work without installing a vinyl tie. The process can save 8.69 seconds. Then performed elimination of work element two at work station 2, which is taking and installing aluminum tape on the capacitor. The work can be done inline preparation so that the operator of the base A assembly station can do the next job. The process can save time of 8.66 seconds. The following elimination process is found in the work elements of 4 work stations, eight spinner lid settings, which are taking the tape and taping wire. The work can be done inline preparation so that the operator of the spinner lid setting work station can do the next job so that eliminating the work element can save time by

\subsection{2 seconds.}

The next step is to combine work elements 5, 8 , and 9 at work station 9 . Take the washer and rotate the timer, tie the vinyl, tie it to the washer machine and rotate the timer with a time of 6.76 seconds. Decompose the wire winding on the wash and spin timer with the time of 1.71 seconds, and tidy up the wiring with a tape with a time of 7.78 seconds. The work can be done inline preparation so that the operator of the work station nine can do the next job. Elimination is then performed on the work elements of 7 stations 11 , which is taking an orange to join with fuse then twister. The work can be done inline preparation so that the operator of the work station 11 can do the next job. With the elimination process, motion elements that are not needed during the assembly process can be reduced to save time by 49.27 seconds.

\section{b. Combine}

A combined method is a method of combining several work elements into one so that it can reduce processing time. Improvement of work elements by combining work station three on work elements 1 and 2 in ECRS 5. The work can be combined into a component of movement, and grease to the hole can be done inline preparation or when the operator is at rest so that operator at work station three can do the next job. With the incorporation of the work, the element is expected to have a time of 1.39 seconds.

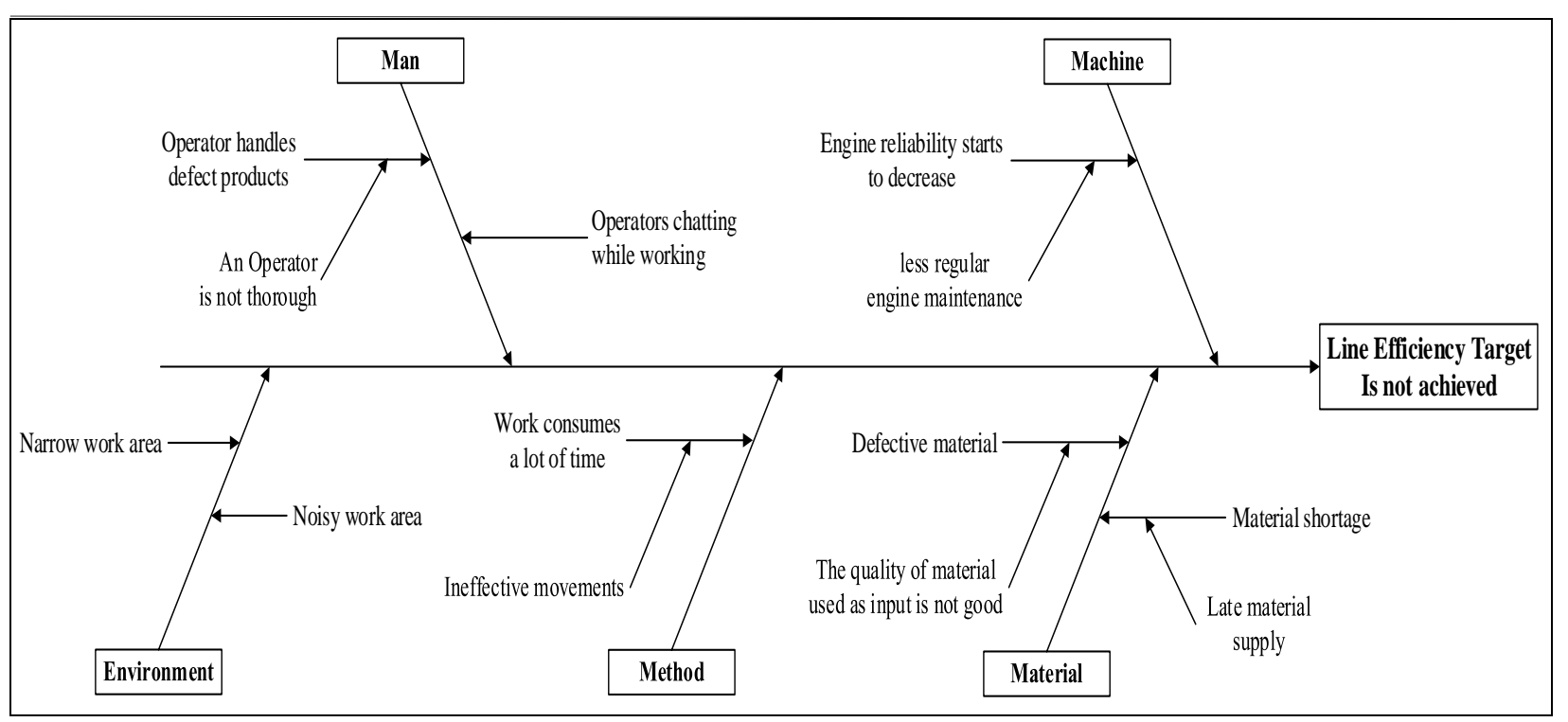

Fig. 1. Cause effect diagram 


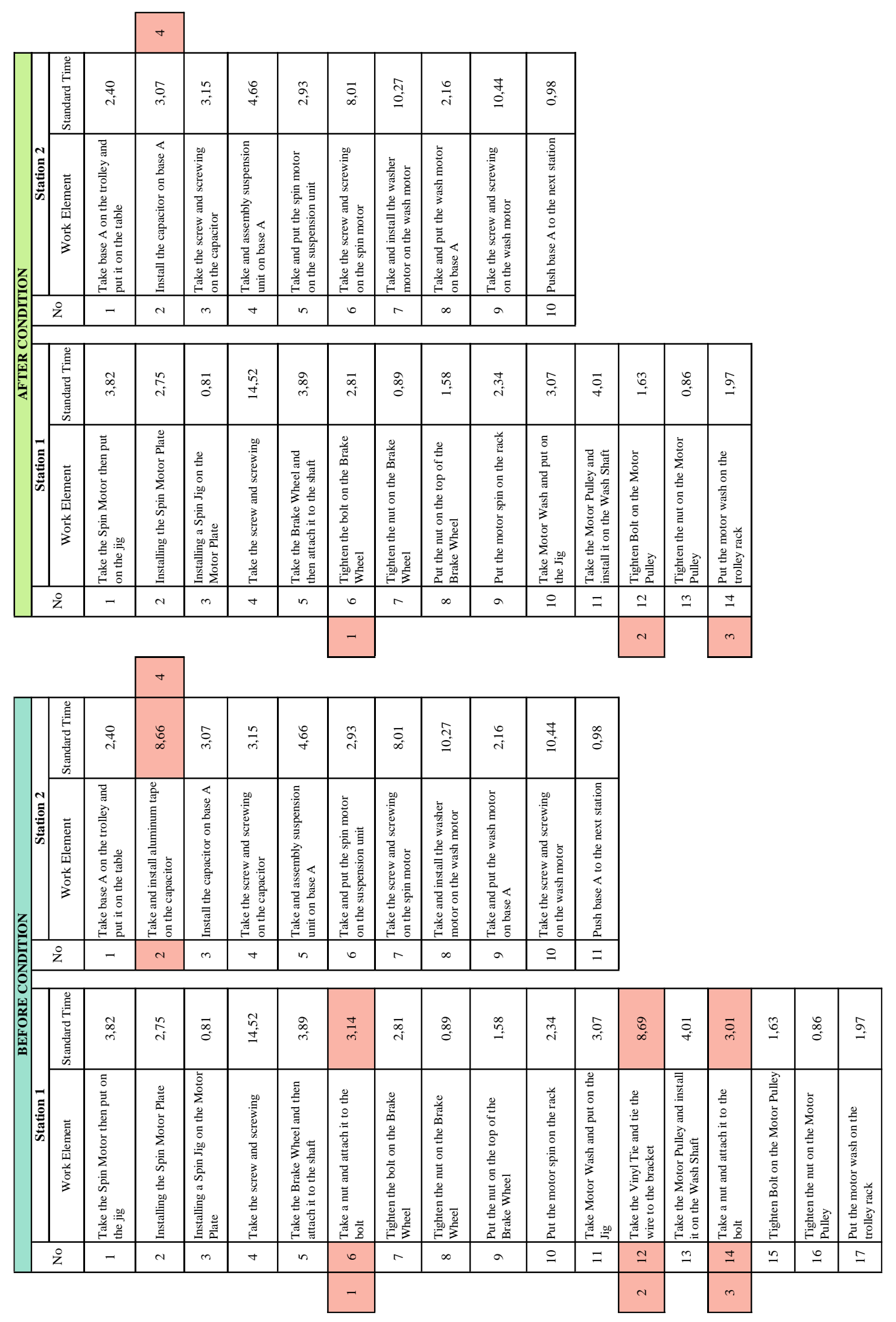

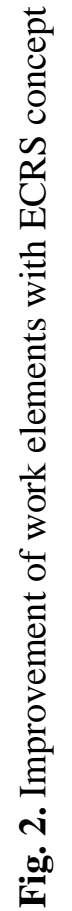




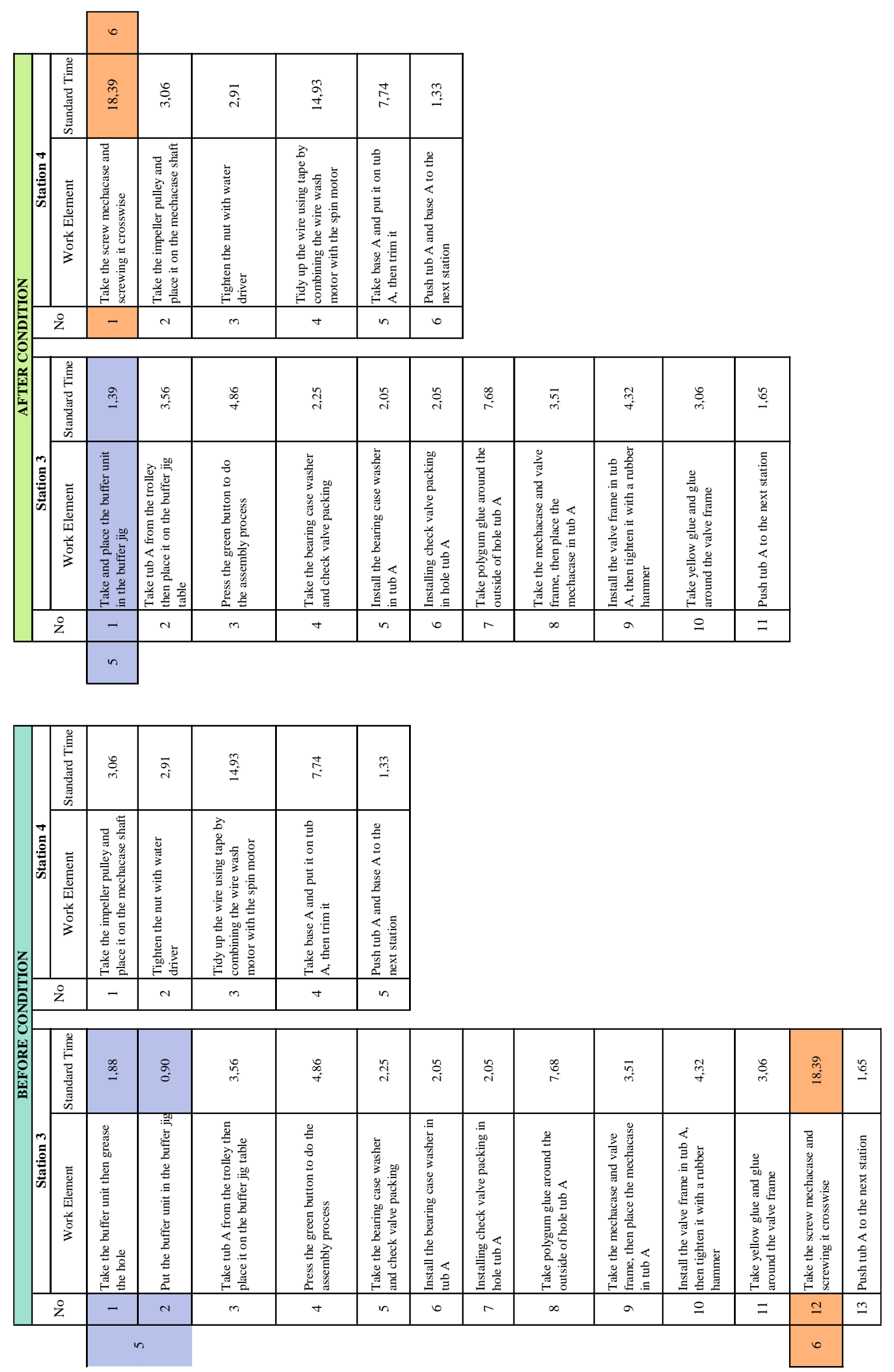




\begin{tabular}{|c|c|c|c|c|c|c|c|c|}
\hline & \multirow{2}{*}{\multicolumn{5}{|c|}{$r$}} \\
\hline & & & & & & & & \\
\hline \multirow[b]{2}{*}{$z^{0}$} & 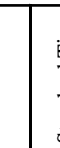 & 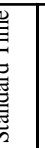 & $\vec{i}$ & $\stackrel{\circ}{m}$ & $\begin{array}{l}\overrightarrow{\mathcal{g}} \\
\vec{f}\end{array}$ & 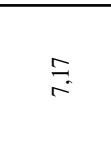 & $\stackrel{\infty}{\stackrel{\infty}{n}} \stackrel{2}{n}$ & $\vec{m}$ \\
\hline & 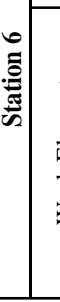 & 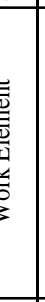 & 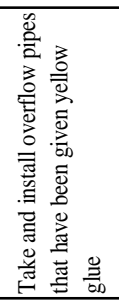 & 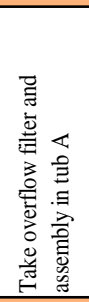 & 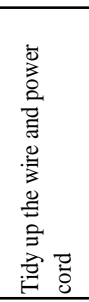 & 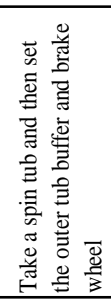 & 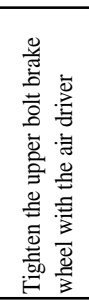 & 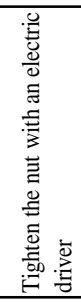 \\
\hline$\overline{\bar{\theta}}$ & z & & - & N & $m$ & + & in & 0 \\
\hline 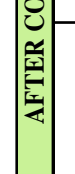 & 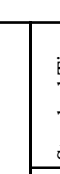 & 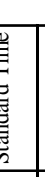 & $\stackrel{m}{\stackrel{m}{2}}$ & $\stackrel{f}{f}$ & $\begin{array}{l}\text { בิ } \\
=\end{array}$ & $\stackrel{5}{\sigma}$ & $\underset{i}{:}$ & ले \\
\hline & ) & 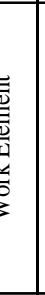 & 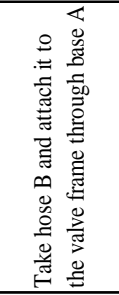 & 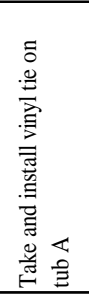 & 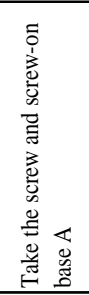 & 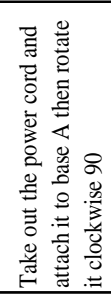 & 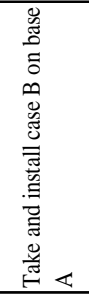 & 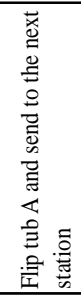 \\
\hline & z & & - & 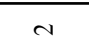 & $m$ & $\nabla$ & in & 0 \\
\hline
\end{tabular}

\begin{tabular}{|c|c|c|c|c|c|c|c|}
\hline & 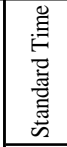 & $\vec{i}$ & $\vec{g}$ & $\cong$ & $\begin{array}{c}\infty \\
\stackrel{\infty}{m} \\
m\end{array}$ & $\vec{m}$ & बे \\
\hline हू & 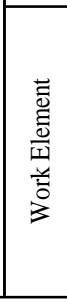 & 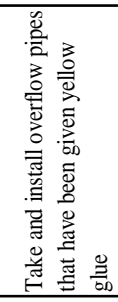 & 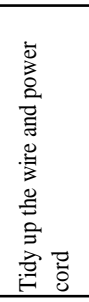 & 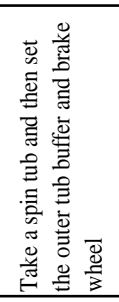 & 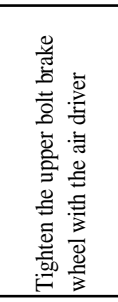 & 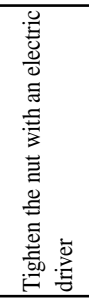 & 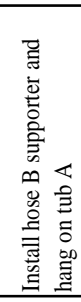 \\
\hline 妾 & $z$ & - & $\sim$ & m & + & $n$ & 0 \\
\hline 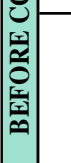 & 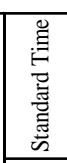 & $\stackrel{m}{2}$ & f & ?ִ & $\underset{a}{a}$ & : & $\stackrel{\infty}{\sim}$ \\
\hline$\ddot{~}$ & 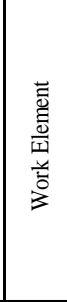 & 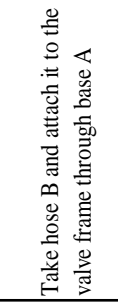 & 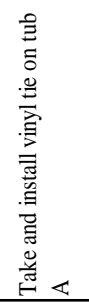 & 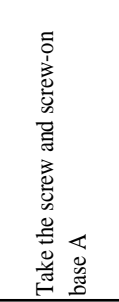 & 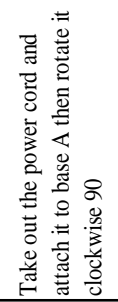 & 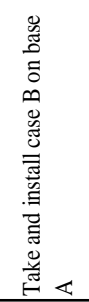 & 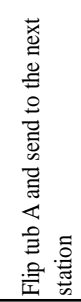 \\
\hline & 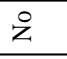 & - & $\mathrm{N}$ & $m$ & + & $n$ & 6 \\
\hline
\end{tabular}



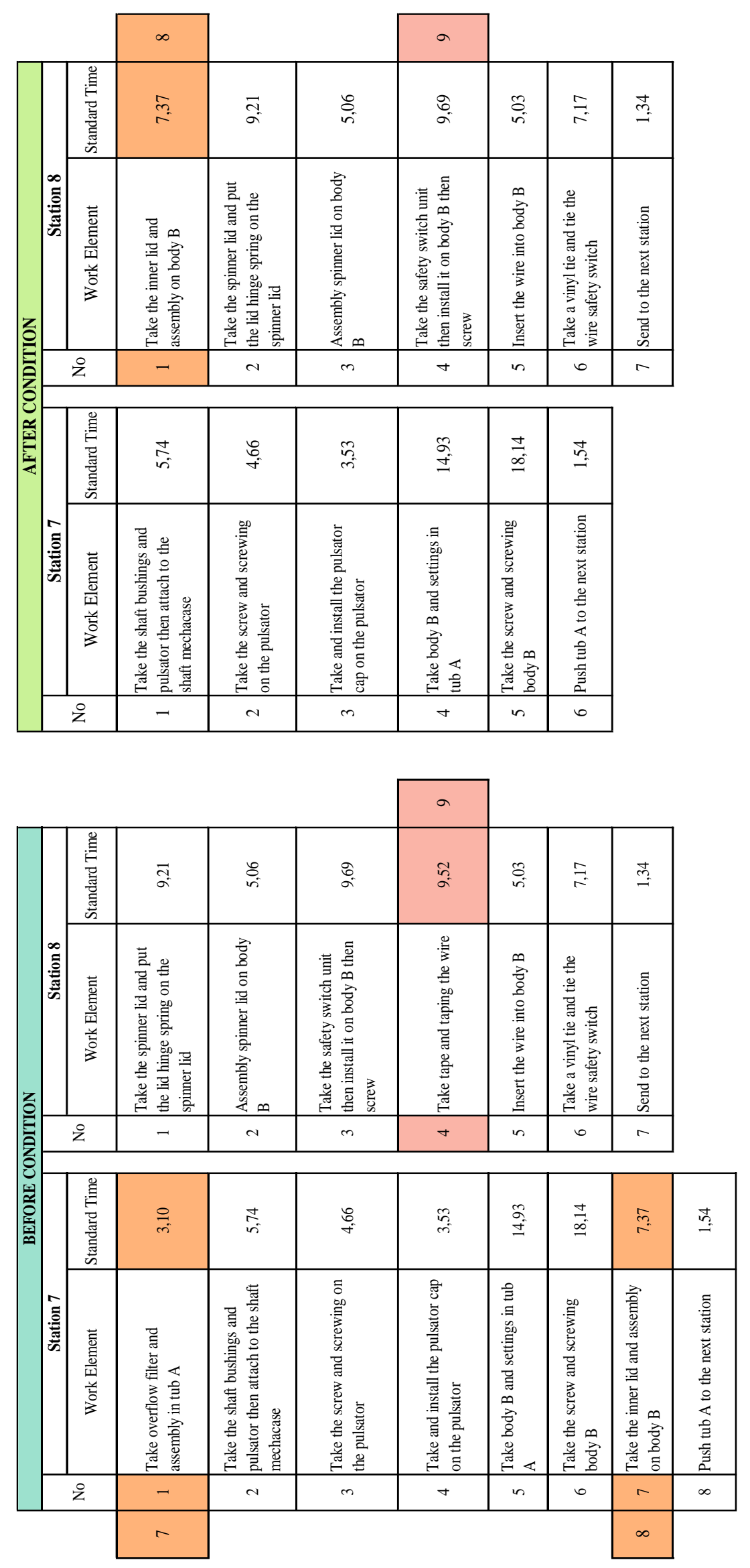


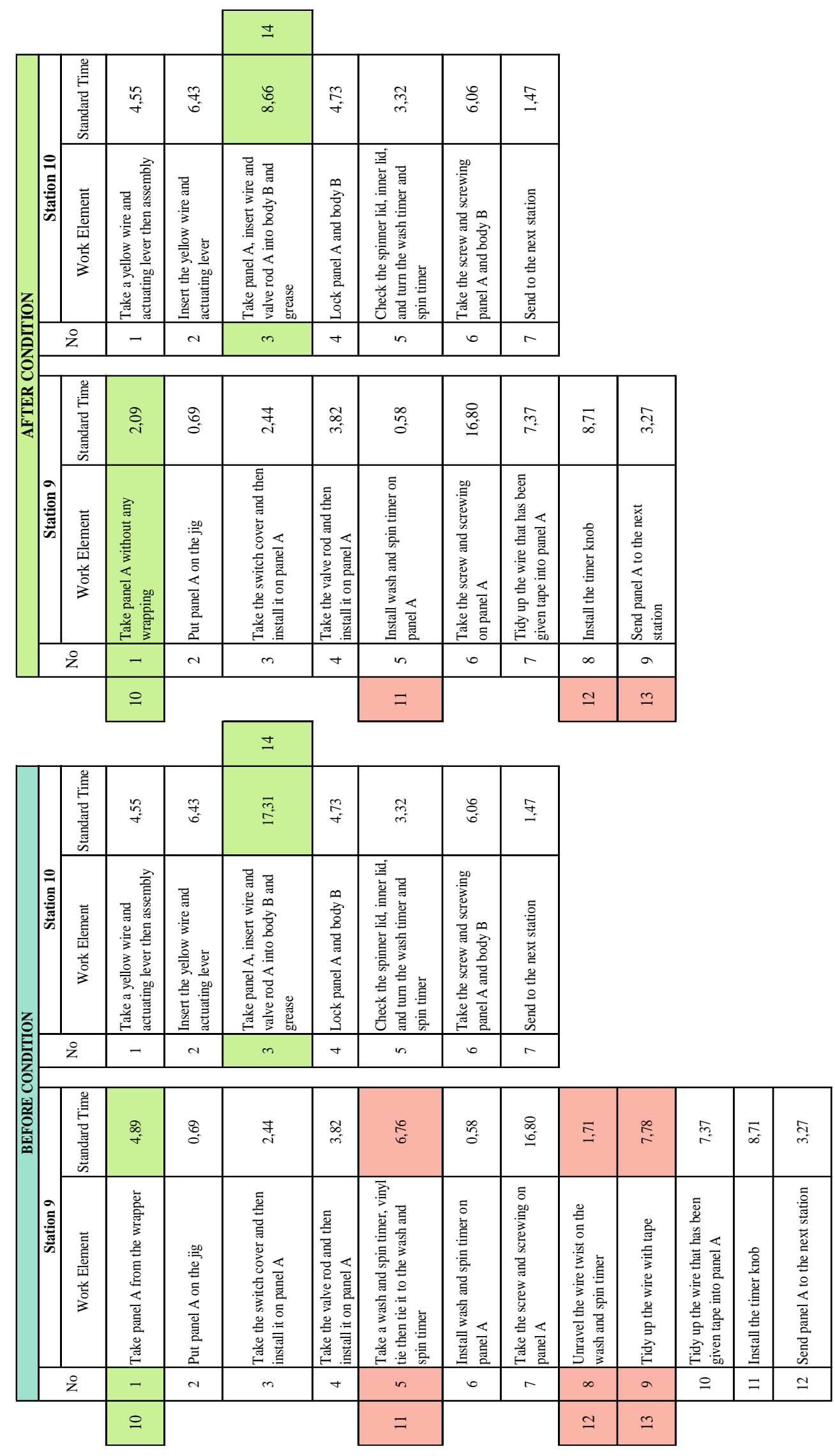

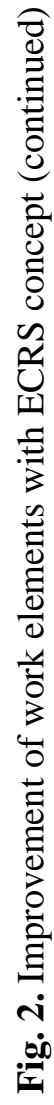




\begin{tabular}{|c|c|c|c|c|c|c|c|c|c|c|}
\hline & 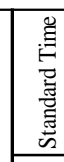 & $\begin{array}{l}\text { ho } \\
\text { in }\end{array}$ & $\stackrel{\circ}{n}$ & $\stackrel{\approx}{\sigma}$ & $\begin{array}{l}n \\
b \\
+ \\
+\end{array}$ & $\underset{\substack{f \\
i}}{ }$ & no & $\stackrel{\vec{\circ}}{+}$ & & \\
\hline $\mid \frac{7}{3}$ & 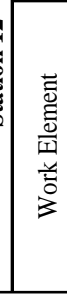 & 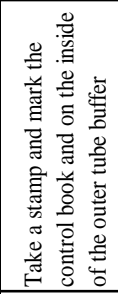 & 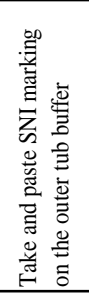 & 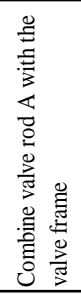 & 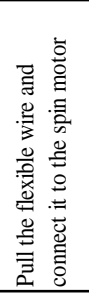 & 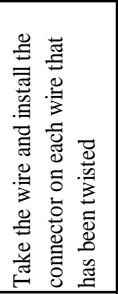 & 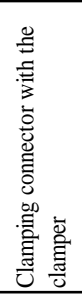 & 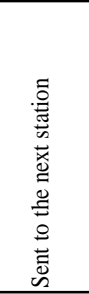 & & \\
\hline 玄 & z & - & $\sim$ & $m$ & + & in & 0 & $r$ & & \\
\hline 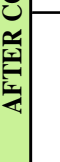 & 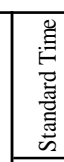 & â & $\stackrel{\vec{m}}{\vec{r}}$ & $\begin{array}{l}\bar{n} \\
\text { in }\end{array}$ & $\begin{array}{l}\tilde{N} \\
\text { in }\end{array}$ & న్ & $\overbrace{\hat{\sigma}}$ & $\begin{array}{l}0 \\
i \\
i\end{array}$ & $\stackrel{f}{m}$ & $\underset{i}{F}$ \\
\hline I & 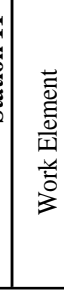 & 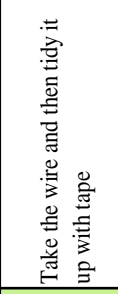 & 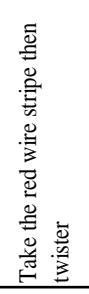 & 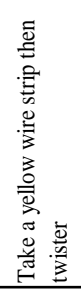 & 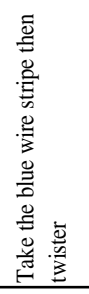 & 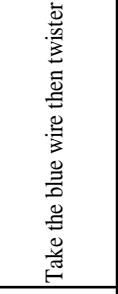 & 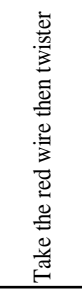 & 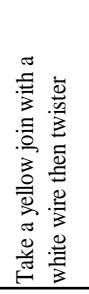 & 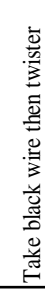 & 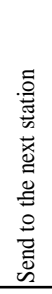 \\
\hline & z & - & $\sim$ & $m$ & 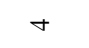 & in & 0 & $r$ & $\infty$ & $a$ \\
\hline
\end{tabular}

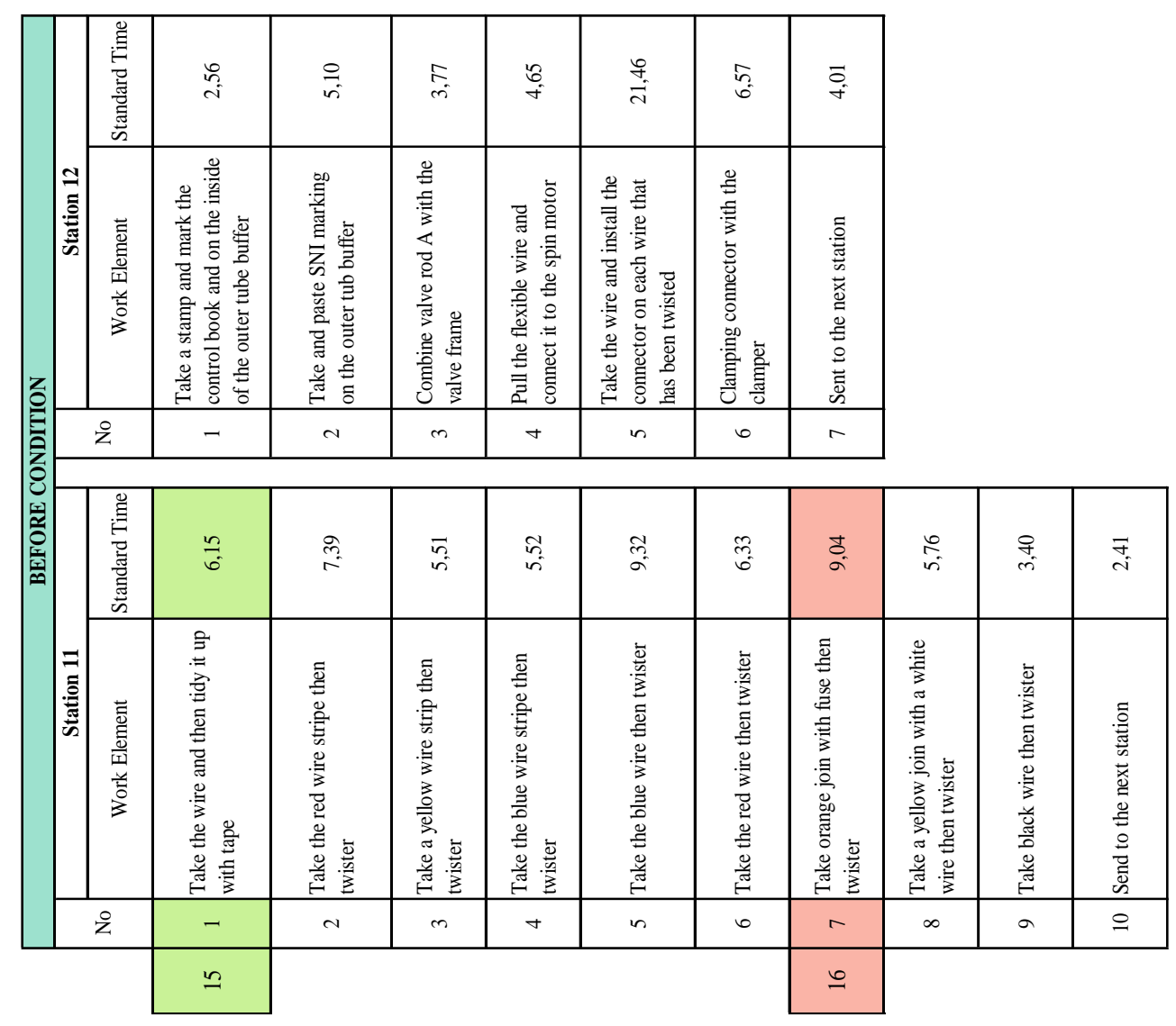




\section{c. Re-arrange}

Re-arrange method is a method that rearranges work elements so that they get a balanced cycle time between workstations. Repairing work elements by re-arranging is found in ECRS 6, 7, and 8. These changes occur in the work station three on work element 12 , which is to take the screw mecha box and screwing across. This work element is transferred to the work station 4. The removal of this work element is intended as a way of equalizing the work elements to increase the efficiency of productivity of the line assembly. Re-arranging is done at the work station seven on work element one that is taking overflow filters and assembly in tub A. The work can be moved to the station spin tub setting work to of equalizing work elements and reduce the bottleneck on the assembly line. The re-arrange process is also carried out at the work station seven on work element 7 , which is to take the inner lid and assembly on the body B. The work can be moved to the work station eight as a way of equalizing work elements to reduce bottlenecks in the line assembly.

\section{d. Simplify}

Improvements to the work element by simplifying are found in ECRS 10, 14, and 15. The simplification of the work element is carried out at work station nine on work element 1 , which is to take panel A from the wrapper. The work element of "taking panel A from the wrapper" is simplified; the new work element is "taking panel A without the wrapper." The work of taking panel A from the wrapper is considered ineffective because the supplier in the warehouse can do the job of removing panel A so the operator can do the next task without having to take panel A from the wrapper. Simplification of the work element can be expected to have a time of 2.09 seconds. Simplified is also done on the work station 10. Namely, the work element "take panel A, insert the wire and valve rod A into body B and grease". The work can be simplified by using one clamp attached to the wire and one clamp attached to the valve rod A. The clamp is small. It has a heavyweight so that when the operator inserts wire and valve rod $\mathrm{A}$ into body $\mathrm{B}$, wire and valve rod A can immediately go down to the bottom, making it easier for the operator of work station 11 to take the cable. Installation of these tools can be done inline preparation. That way, the work is expected to have a processing time of 8.66 seconds. The simplified process also takes place at the work station 11 on work element 1 , which is making the wire and then tidying it with tape. The work can be simplified by using tools that have been used on work station ten so that operator of the work station 11 can do the work of removing the clamp from the wire and straightening the wire directly with tape. The work is expected to have a processing time of 2.05 seconds.

Table 1. Comparison before and after improvement

\begin{tabular}{|c|c|c|}
\hline Indicator & $\begin{array}{c}\text { Before } \\
\text { improvement }\end{array}$ & $\begin{array}{c}\text { After } \\
\text { improvement }\end{array}$ \\
\hline Target Takt & 35.25 & 35.25 \\
\hline Time $\left(T_{T t}\right)$ & seconds/unit & seconds/unit \\
\hline Actual Takt & 64.83 & 48.55 \\
\hline Time $\left(T_{T a}\right)$ & seconds/unit & seconds/unit \\
\hline Gap between & 29.58 & 13.30 \\
\hline$T_{T t}$ and $T_{T a}$ & seconds/unit & seconds/unit \\
\hline $\begin{array}{l}\text { Work content } \\
\text { time }\left(T_{w c}\right)\end{array}$ & $\begin{array}{c}597.19 \\
\text { seconds/unit }\end{array}$ & $\begin{array}{c}520,76 \\
\text { seconds/unit }\end{array}$ \\
\hline $\begin{array}{c}\text { Maximum } \\
\text { station time } \\
\left(T_{S}\right)\end{array}$ & $\begin{array}{c}64.83 \\
\text { seconds/unit }\end{array}$ & $\begin{array}{c}48.55 \\
\text { seconds/unit }\end{array}$ \\
\hline $\begin{array}{c}\text { Number of } \\
\text { work stations }\end{array}$ & 12 & 12 \\
\hline $\begin{array}{l}\text { Number of } \\
\text { operators }\end{array}$ & 12 & 12 \\
\hline $\begin{array}{l}\text { Production } \\
\text { Capacity }\end{array}$ & 334 sets & 521 sets \\
\hline $\begin{array}{l}\text { Production/ } \\
\text { Head/Hour }\end{array}$ & 3.55 sets & 5.54 sets \\
\hline $\begin{array}{c}\text { Process Time } \\
\text { Balance }\end{array}$ & 16.89 minutes & 10.84 minutes \\
\hline $\begin{array}{l}\text { Efficiency } \\
\qquad\left(E_{b}\right)\end{array}$ & $76.76 \%$ & $89.39 \%$ \\
\hline
\end{tabular}

After improvements to the work methods on the assembling line obtained $89.39 \%$. This shows an increase in line efficiency by $12.63 \%$, and after improvement, the bottleneck at work station nine has been removed successfully. This means that the distribution of workload for each work station is more evenly compared to the conditions before the improvement (Table 1).

A similar result was found by [26], [27] where the line efficiency was before improvement in a row equal to $85.08 \%, 91 \%$. After development 
made with the ECRS concept, the line efficiency increased until $94.18 \%$, 95\%. Based on the acquisition of the line efficiency values, it shows that the amount of line efficiency increases after the equalization of work and ECRS.

Based on the comparison before and after the improvement shown in Fig. 3 and Fig. 4, it appears that there is a condition of balance between stations after repairs. Before repairs, it was seen that station 4 and station 6 had less workload compared to other stations, and station 9 had a high workload with an actual takt time of 64.83 seconds/unit. After improving the work method, the operator workload becomes flattered so that it can reduce the real takt time by 48.55 seconds/unit.

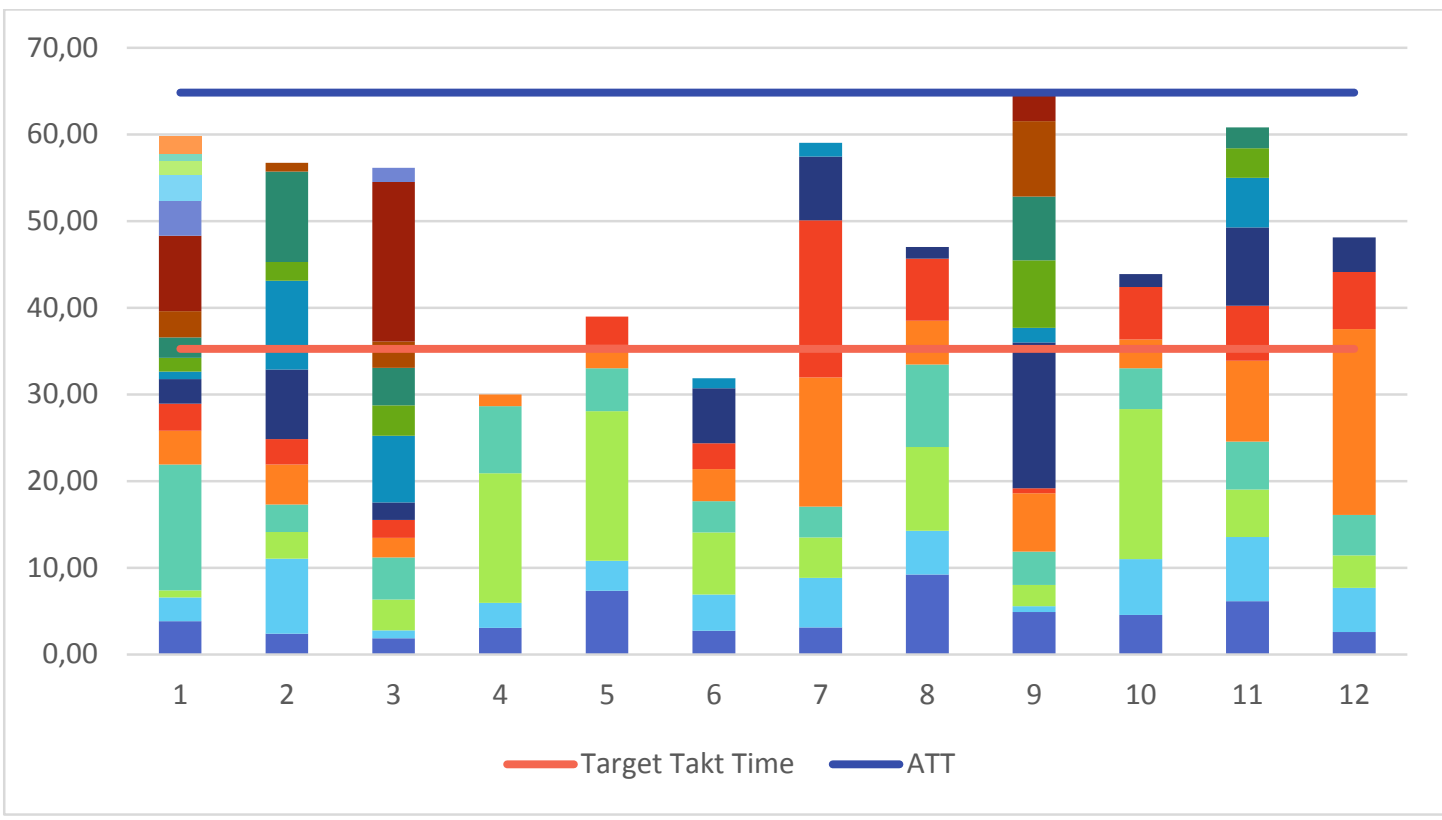

Fig. 3. Line balancing of each work station before the improvements

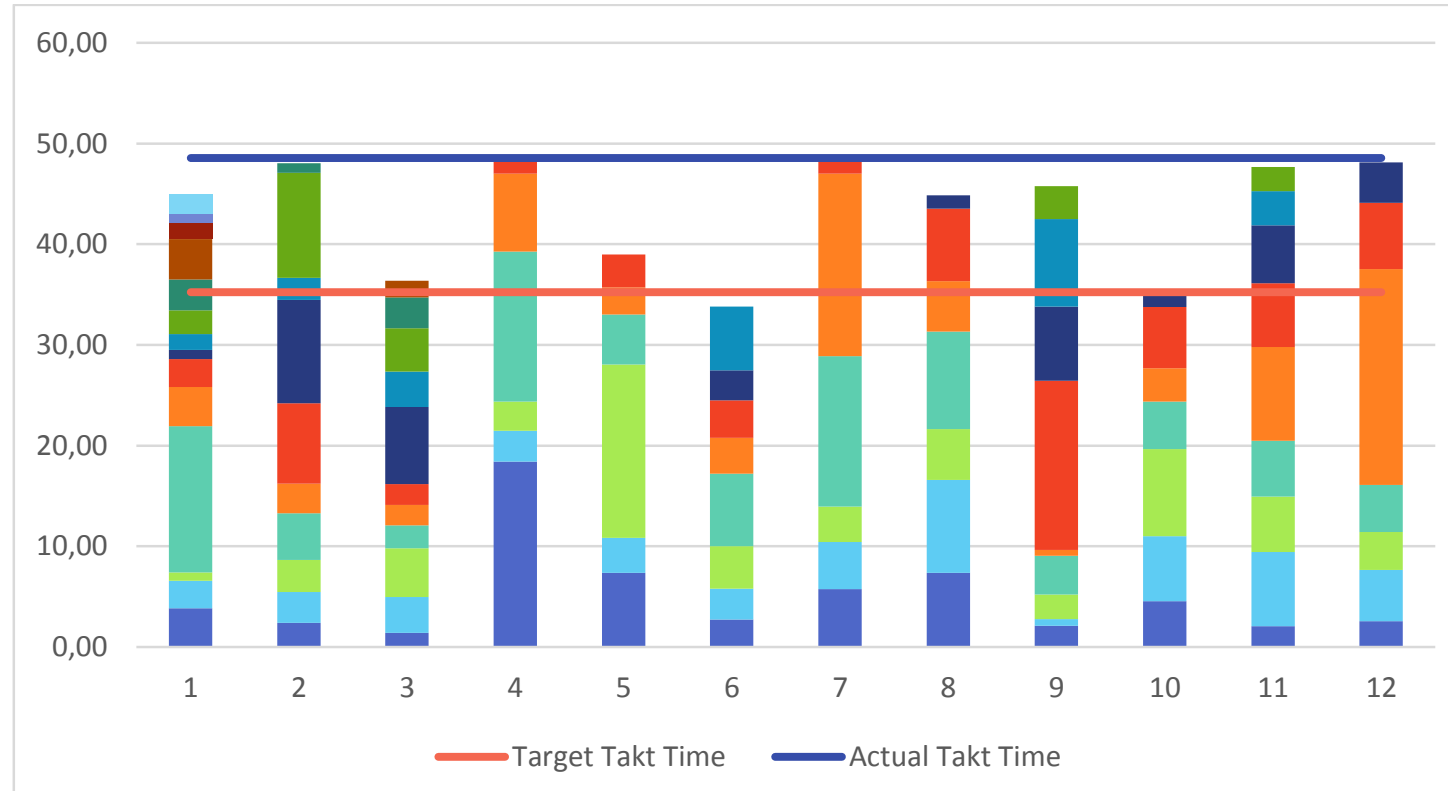

Fig. 4. Line balancing of each work station after the improvement 


\section{CONCLUSION}

The results of improvements can improve work methods with path efficiency values from $76.76 \%$ to $89.38 \%$. Thus the ECRS concept can increase the amount of line efficiency in assembly lines. Efforts to increase production targets can be made using the idea of ECRS (Eliminate, Combine, Rearrange, and Simplify), and line balancing. The concept of ECRS can eliminate, combine, rearrange, and simplify the elements of work that are ineffective and inefficient. After improvements to the ECRS concept were carried out, the sequence of assembly processes that had been reduced, combined, rearranged, and simplified the work elements in several work stations was obtained. In this study, this increase can reduce total work content time, improve balance efficiency, reduce balance delays so that the company can achieve production targets due to a decrease in overall cycle time or maximum station time and an increase in production output. Further research is expected to develop the concept of ECRS in other industrial fields accompanied by more efficient methods so that it can adjust to the industrial era 4.0.

\section{REFERENCES}

[1] A. D. Makwana and G. S. Patange, "Strategic implementation of $5 \mathrm{~S}$ and its effect on productivity of plastic machinery manufacturing company," Aust. J. Mech. Eng., pp. 1-10, Oct. 2019, doi: 10.1080/14484846.2019.1676112.

[2] Ashish Kalra, Sachin Marwah, Sandeep Srivastava, and Rajesh Bhatia, "Productivity Improvement in Assembly Line of Automobile Industry by Reducing Cycle time of Operations," Int. J. Eng. Res., vol. 5, no. 05, pp. 28-31, May 2016, doi: 10.17577/IJERTV5IS050185.

[3] A. Jaggi, S. Patra, and D. S. Chaubey, "Application of line-balancing to minimize the Idle time of workstations in the production line with special reference to automobile industry," Int. J. IT, Eng. Appl. Sci. Res., vol. 4, no. 7, pp. 8-12, 2015, available at: Google Scholar.

[4] D. Battini, X. Delorme, A. Dolgui, A. Persona, and F. Sgarbossa, "Ergonomics in assembly line balancing based on energy expenditure: a multi-objective model," Int. J. Prod. Res., vol. 54, no. 3, pp. 824-845, Feb. 2016, doi: 10.1080/00207543.2015.1074299.

[5] R. Rahayu, "Pengaruh Aplikasi Strategi Just In Time Terhadap Efektivitas dan Efisiensi Biaya Produksi Pada PT. Santosa Jaya Abadi Sidoarjo," EKUITAS (Jurnal Ekon. dan Keuangan), vol. 9, no. 4, pp. 439-463, 2018, available: https://analytics.stiesia.ac.id/ekuitas/articl e/view/299.

[6] N. T. Lam, L. M. Toi, V. T. T. Tuyen, and D. N. Hien, "Lean Line Balancing for an Electronics Assembly Line," Procedia CIRP, vol. 40, no. 1, pp. 437-442, 2016, doi: 10.1016/j.procir.2016.01.089.

[7] L. Botti, C. Mora, and A. Regattieri, "Integrating ergonomics and lean manufacturing principles in a hybrid assembly line," Comput. Ind. Eng., vol. 111, no. 5, pp. 481-491, Sep. 2017, doi: 10.1016/j.cie.2017.05.011.

[8] R. Soesilo, "Meningkatkan Output Dengan Melakukan Perubahan Tata Letak di Area Produksi," J. Ind. Eng. Manag., vol. 2, no. 2, pp. 23-31, Dec. 2017, doi: 10.33536/jiem.v2i2.149.

[9] R. M. Yusuff and N. S. Abdullah, "Ergonomics as a lean manufacturing tool for improvements in a manufacturing company," in Proceedings of the International Conference on Industrial Engineering and Operations Management, 2016, pp. 581-588, available: http://ieomsociety.org/ieom_2016/pdfs/16 4.pdf.

[10] M.-N. Nguyen and N.-H. Do, "Reengineering Assembly Line with Lean Techniques," Procedia CIRP, vol. 40, pp. 590-595, 2016, doi: 10.1016/j.procir.2016.01.139.

[11] J. Dinis-Carvalho, L. Guimaraes, R. M. Sousa, and C. P. Leao, "Waste identification diagram and value stream mapping," Int. J. Lean Six Sigma, vol. 10, no. 3, pp. 767-783, Aug. 2019, doi: 10.1108/IJLSS-04-2017-0030.

[12] P. Srinivasa Rao and M. Niraj, "A case 
study on implementing lean ergonomic manufacturing systems (LEMS) in an automobile industry," IOP Conf. Ser. Mater. Sci. Eng., vol. 149, pp. 1-9, Sep. 2016, doi: 10.1088/1757899X/149/1/012081.

[13] I. Alsaffar and H. Ketan, "Reviewing the Effects of Integrated Lean Six Sigma Methodologies with Ergonomics Principles in an Industrial Workstation," IOP Conf. Ser. Mater. Sci. Eng., vol. 433, no. 1, pp. 1-13, Nov. 2018, doi: 10.1088/1757-899X/433/1/012060.

[14] A. N. M. Amin, W. H. W. Mahmood, S. R. Kamat, and I. Abdullah, "Conceptual framework of lean ergonomics for assembly process: PDCA approach," $J$. Eng. Sci. Res., vol. 2, no. 1, pp. 51-62, 2018, doi: 10.26666/rmp.jesr.2018.1.9.

[15] R. Khani Jazani, A. Salehi Sahlabadi, and S. S. Mousavi, "Relationship Between Lean Manufacturing and Ergonomics," in International Conference on Applied Human Factors and Ergonomics, Springer, 2018, pp. 162-166. doi: 10.1007/978-3-319-60474-9_15.

[16] H. Murnawan, "Perencanaan Produktivitas Kerja Dari Hasil Evaluasi Produktivitas Dengan Metode Fishbone Di Perusahaan Percetakan Kemasan Pt. X," HEURISTIC J. Tek. Ind., vol. 11, no. 01, pp. 27-46, 2014, available: http://jurnal.untagsby.ac.id/index.php/HEURISTIC/article/v iew/611.

[17] M. I. Fajrianto, T. G. Amran, and N. Azmi, "Rancang Bangun Model Lean Productivity Dengan Pendekatan Objective Matrix - Value Stream Mapping - ECRS (Studi Kasus: PT. X)," J. Tek. Ind., vol. 5, no. 3, pp. 61-72, 2017, doi: 10.25105/jti.v5i3.1521.

[18] B. Suhardi, N. Anisa, and P. W. Laksono, "Minimizing waste using lean manufacturing and ECRS principle in Indonesian furniture industry," Cogent Eng., vol. 6, no. 1, pp. 1-13, Jan. 2019, doi: 10.1080/23311916.2019.1567019.

[19] C. Kasemset, C. Boonmee, and P. Khuntaporn, "Application of MFCA and
ECRS in waste reduction: A case study of electronic parts factory," in Proceedings of the 2016 International Conference on Industrial Engineering and Operations Management, 2016, pp. 1844-1853, available:

http://ieomsociety.org/ieom_2016/pdfs/53 7.pdf.

[20] I. N. Fadlil and C. N. Rosyidi, "Improvement of work processes and methods to achieve production targets using VA/NVA analysis, ECRS and line balancing," in AIP Conference Proceedings, 2020, vol. 2217, no. 1, pp. 110, doi: 10.1063/5.0000657.

[21] G. J. Pawar, N. S. Sirdeshpande, A. B. Atram, and P. R. Patil, "Reduction in setup change time of a machine in a bearing manufacturing plant using SMED and ECRS," Int. J. Eng. Res., vol. 3, no. 5, pp. 321-323, May 2014, doi: 10.17950/ijer/v3s5/506.

[22] T. G. Amran and N. C. Wibowo, "Perbaikan Proses Produksi Sistem Pengereman Kendaraan Bermotor Dengan Metode ECRS-Based Line Balancing," in Prosiding Seminar Nasional Pakar, 2018, pp. 193-204, available: https://www.trijurnal.lemlit.trisakti.ac.id/p akar/article/view/2686.

[23] Y. Indrawan and N. L. P. Hariastuti, "Minimalisasi bottleneck proses produksi dengan menggunakan metode line balancing," Jur. Tek. Ind. Inst. Teknol. Adhi Tama Surabaya, vol. 6, no. 1, pp. 110, 2014, available: http://jurnal.itats.ac.id/wpcontent/uploads/2013/06/MinimalisasiBottleneck-Proses_61.pdf.

[24] V. F. Daelima, E. Febianti, and M. A. Ilhami, "Analisis Keseimbangan Lintasan untuk Meningkatkan Kapasitas Produksi dengan Pendekatan Line Balancing dan Simulasi," J. Tek. Ind. Untirta, vol. 1, no. 2, pp. 107-113, 2013, available: http://jurnal.untirta.ac.id/index.php/jti/arti cle/view/129.

[25] H. Sofyan, M. Nadeak, and T. B. Prasetyo, "Peningkatan Produktivitas pada Proses Assembling Priming Set Melalui 
Perbaikan Stasiun Kerja Menggunakan Metode Time Study," J. Ilm. Trendtech, vol. 3, no. 1, pp. 38-44, 2018, available: http://jurnalstttexmaco.ac.id/index.php/JT T/article/view/32.

[26] D. Pujotomo and D. N. Rusanti, "Usulan Perbaikan Untuk Meningkatkan Produktivitas Fillingplant Dengan Pendekatan Lean Manufacturing Pada PT. Smart Tbk Surabaya," J@TI UNDIP J. Tek. Ind., vol. 10, no. 2, pp. 123-132, Jun. 2015, doi: 10.12777/jati.10.2.123-132.

[27] M. B. Ralph, Motion and Time Study Design and Measurement of Work. 7th ed. Singapore: John Wiley \& Sons, 1980, available at: Google Scholar.

[28] H. Purnomo, Pengantar Teknik Industri. Yogyakarta: Graha Ilmu, 2004, available at: Google Scholar.

[29] R. D. Astuti and I. Iftadi, Analisis dan Perancangan Sistem Kerja. Sleman: Deepublish, 2016, available at: Google Scholar.

[30] M. P. Groover, Automation, production systems, and computer-integrated manufacturing. Upper Saddle River: Pearson, 2007, available at: Google Scholar. 